Lingua e Literatura, no 24, p. 67-75, 1998.

\title{
HEROÍSMO E MARGINALIDADE: HERANÇAS QUIXOTESCAS *
}

\section{Maria Augusta da Costa Vieira **}

\begin{abstract}
REsUMO: Estando nos umbrais de um novo gènero literário, o Dom Quixote gerou uma ampla descendência de narrativas que incorporam diferentes aspectos de sua construçāo. $O$ presente artigo se detèm inicialmente em algumas das marcas quixotescas de caráter estético presentes em Memórias póstumas de Brás Cubas. Em seguida, aborda Triste fim de Policarpo Guaresma, destacando outro tipo de filiaçāo que se pauta pela constituiçāo do herói, tendo em conta as imbricaçōes entre o épico e o lírico, além da junçāo paradoxal entre heroismo e loucura.
\end{abstract}

Palavras-chave: Dom Quixote, romance, herói, gēneros literários, narrador/leitor, armas e letras.

Conta-se, no Livro X da República de Platão, que no momento em que as almas chegaram à outra vida, lhes foi concedido o direto de escolher qual a próxima existência que gostariam de ter. O mais curioso era que a maior parte das almas fazia sua opçāo de acordo com os hábitos de sua vida anterior. Por exemplo, a alma que anteriormente havia pertencido a Orfeu escolheu, para sua próxima existência, uma vida de cisne "por ódio à raça das mulheres, porque, devido a ter sofrido a morte nas mãos delas, não

(*) O presente trabalho, um tanto modificado, foi apresentado no "Simposio Internacional Cervantes en el mundo" em comemoração dos 450 anos do nascimento de Cervantes, realizado na Universidade de Nanjing, China, em setembro de 1997. A participação no referido evento contou com o apoio da FAPESP.

$\left({ }^{* *}\right.$ Professora do Departamento de Letras Modernas, FFLCH-USP. 
queria nascer de uma mulher" Os que haviam sido injustos desejavam para a próxima existência a transformaçāo em animais selvagens e os que haviam sido justos optavam pelos animais domésticos. O último a ser interrogado sobre seus desejos foi Ulisses que, tendo se recordado dos intensos trabalhos que havia tido, projetou para sua próxima existência o "descanso da ambição" e uma "vida de um particular tranqüilo"l Com isso, Ulisses escolhia um destino mais modesto para o herói de modo que na próxima vida, de certa forma, ele teria uma condição mais equivalente à dos demais mortais.

Em alguma medida, a própria trajetória de Dom Quixote - o inusitado cavaleiro da Mancha - conta a história dessas duas vidas do herói, ou melhor, da passagem de uma existência para a outra pois foi o primeiro personagem da literatura ocidental que, após inúmeras aventuras e batalhas inglórias, pouco antes de sua morte, acabou redimensionando os parâmetros de sua própria existência, constatando a impossibilidade de ser um cavaleiro andante, e pior, descobrindo a falsidade das novelas de cavalaria. Assim, o Cavaleiro da Triste Figura encontra-se nas origens desse novo herói imaginado por Ulisses que, num sentido genérico, teve que se conformar com a dissolução da idéia tradicional de heroísmo e, ao mesmo tempo, democratizar sua condiçāo de personagem literário ${ }^{2}$ Dessa forma, o romance como gênero literário está em constante diálogo, mais ou menos explícito, com a obra de Cervantes. Nesse sentido, o estudo da recepção do Quixote num sentido amplo poderá abarcar as mais diversas modalidades do gênero.

(1) PLATÃO, República. Introdução e notas de M. Helena da Rocha Pereira. Lisboa, Fundação Calouste Gulbenkian, 1983, 4. ed., p. 498.

(2) Como diz E. C. Riley, no amplo processo de maturação do romance como gênero literário, o Quixote significa um ponto de interseção entre o velho e novo, entre o herói elevado e aristocrático e o herói do romance que tem desejos rnas que conta, ao mesmo tempo, com inúmeras limitaçōes. (Ver "Whatever Happened to Heroes? Don Quixote and some Major European Novels of the Twentieth Century" in Cervantes and the Modernists - The Question of Influence. Ed. by E. Williamson. London/Madrid, Tamesis, 1994, p. 73-84). 
O presente trabalho faz parte de uma pesquisa em andamento que trata justamente da recepção do Quixote no contexto brasileiro, considerada a partir de determinados critérios que, por questōes de ordem metodológica, partem de dois parâmetros designados metaforicamente por eixo das armas e eixo das letras.

A relaçāo que se estabelece com o Quixote a partir das letras não se centra de forma privilegiada na história e sim na forma de contá-la, envolvendo a tensão que reina no diálogo implícito ou explícito entre o narrador e o leitor. É como se na raiz do gênero romance houvesse um questionamento acerca do seu próprio modo de existir, isto é, uma indagação acerca da composiçāo, do emissor e do receptor. O eixo das letras supōe portanto conexões com a obra cervantina que se apresentam de forma mais difusa e estão centradas nas similaridades presentes na perspectiva estética. Este seria o caso, por exemplo, de Memórias póstumas de Brás Cubas (1881) de Machado de Assis, especialmente nos momentos em que o narrador se dirige diretamente ao leitor

O Quixote, além de ser um romance de aventuras, concede uma grande atenção ao leitor e à prática da leitura. As vozes narrativas desdobradas cuidam do leitor e o conduzem por percursos variados de modo que a leitura realizada pelo leitor virtual do Guixote jamais corresponderá às inúmeras leituras das novelas de cavalaria empreendidas por Alonso Quijano. Memórias póstumas de Brás Cubas, por outro lado, não se assemelha à obra de Cervantes se considerarmos as veleidades heróicas e os idealismos quixotescos. Trata-se de um relato autobiográfico que se caracteriza essencialmente pela ausência de ações dignas de nota, ao contrário do cavaleiro que tem o objetivo de se imortalizar pela relevância de seus atos. O grande paradoxo do romance - o relato de um narrador defunto - incide na inverossimilhança, no entanto, pouco a pouco, o texto torna-se plausivel graças especialmente ao diálogo intenso que se estabelece entre narrador e leitor.

No Quixote, por sua vez, o narrador não perde de vista o leitor, sobretudo na segunda parte quando o narrador cria um jogo com a própria condição do leitor: um jogo que ao mesmo tempo encobre e descobre a voz narrativa, ao 

quixotescas

conceder credibilidade e simultaneamente assinalar o caráter duvidoso do puntual Cide Hamete Benegeli e do tradutor. De qualquer modo, ainda que algumas intervençōes metalingüisticas do narrador se refiram essencialmente à questão da politica intrinseca da escritura, isto é, a uma tensão que gira em torno do poder, o leitor do Quixote nāo se sente diminuído diante da obra ${ }^{3}$ No capítulo XLIV da segunda parte da obra, há um fragmento que revela de forma exemplar esta tensāo de ordem política entre narrador e leitor. Trata-se, como diz o tradutor, de um momento de desabafo e de queixas "intraduziveis" do autor ficcional, Cide Hamete Benengeli ${ }^{4} \mathrm{O}$ autor confessa já nāo suportar o peso da escritura em funçāo das alteraçōes que fez para atender ao gosto do público. Um público que mostrou suas preferências pelas aventuras de Dom Quixote e Sancho em detrimento das histórias intercaladas que aparecem especialmente na primeira parte da obra. Sem dúvida, os desabafos de Cide Hamete constituem uma explicitação de objetivos estéticos que, nesse momento, opta pela concentração nos protagonistas em detrimento dos impulsos imaginativos voltados para a criação de histórias interpoladas. Embora contrariado, o "autor" se rende às preferências do leitor mostrando que, ainda que sua voz

(3) Diz Harold Bloom: "Diante da força de Dom Quixote, o leitor jamais se vê dimuído, só aumentado. O mesmo não se pode dizer de muitos momentos de leitura de Dante, Milton ou Jonathan Swift, cujo Tale of a Tub sempre me parece a melhor prosa da língua depois da de Shakespeare, e no entanto não pára de me reprovar." ( $O$ cânone ocidental. Trad. Marcos Santarrita. Rio de Janeiro, Editora Objetiva, 1995, p. 129).

(4) "Dicen que en el propio original desta historia que se lee que llegando Cide Hamete a escribir este capítulo, no le tradujo su intérprete como él lo había cscrito, que fue un modo de queja que tuvo el moro de sí mismo, por haber tomado entre manos una historia tan seca y tan limitada como esta de Don Quijote y Sancho, por parecerle que sicmpre había de hablar de él y de Sancho, sin osar extenderse a otras digresiones y episodios más graves y más entretenidos; y decía que el ir siempre atenido al entendimiento, la mano y la pluma a escribir de un solo sujeto y hablar por las bocas de pocas personas era un trabajo incomportable, cuyo fruto no redundaba en el de su autor, y que por huir de este inconveniente había usado en la primera parte del artificio de algunas novelas como fucron la 'del curioso impertinente' y la 'del capitán cautivo' que están como separadas de la historia, puesto que las demás que allí se cuentan son casos sucedidos al mismo Don 
seja silenciosa ou pelo menos implícita, o leitor tem mobilidade interpretativa no texto e, além disso, tem poderes no sentido de poder indicar os destinos da narração. Desse modo, deixa vislumbrar que a força imaginativa de um romance não se concentra exclusivamente na história mas também se estende à interlocução.

Algo semelhante ocorre em Memórias póstumas de Brás Cubas que também converte alguns de seus procedimentos composicionais em matéria narrativa de modo a envolver o leitor nas fibras do romance. Por razōes muito semelhantes às do autor ficcional do Quixote, repentinamente, em "O senão do livro" o narrador interrompe o relato e introduz seus comentários sobre o texto e sobre a disparidade que encontra entre seus próprios interesses e os do leitor, denunciando o caráter fastidioso de sua obra ${ }^{5}$. Assim, se estabelece a discórdia entre narrador e leitor pois apresentam motivaçōes contrárias com respeito à forma de conceber e de dispor da matéria narrativa. O narrador, que prefere um estilo sinuoso, joga então com o interesse anedótico e com a motivação linear do leitor. Assim como no Quixote, a intervençāo do narrador tem um propósito estético, disfarçado de declaração de descontentamento por parte do narrador. A partir do enfrentamento criado

Quijote, que no podian dejar de escribirse. También pensó, como él dice, que muchos llevados de la atención que piden las hazañas de Don Quijote, no la darían a las novelas, y pasarían por ellas, o con priesa, o con enfado, sin advertir la gala y artificio que en sí contienen, el cual se mostrara bien al descubierto, cuando por sí solas, sin arrimarse a las locuras de Don Quijote, ni a las sandeces de Sancho, salieran a luz; y así, en esta segunda parte no quiso ingerir novelas sueltas ni pegadizas, sino algunos episodios que lo pareciesen nacidos de los mesmos sucesos que la verdad ofrece, y aún éstos, limitadamente y con solas las palabras que bastan a declararlos; y pues se contiene y cierra en los estrechos límites de la narración, teniendo habilidad, suficiencia y entendimiento para tratar del universo todo, pide no se desprecie su trabajo, y se le den alabanzas, no por lo que escribe, sino por lo que há dejado de escribir." (Don Quijote. Ed. Luis Andrés Murillo. Madrid, Castalia, 1989, T. II, Cap. XLIV, p. 366-367.)

(5) "Começo a arrepender-me deste livro. Não que ele me canse; eu não tenho que fazer; e, realmente, expedir alguns magros capítulos para esse mundo sempre é tarefa que distrai um pouco da eternidade. Mas o livro é enfadonho, cheira a sepulcro, traz certa contração cadavérica; vício grave, e aliás infimo, porque o maior defeito deste livro és tu, 

quixotescas

entre narrador e leitor se desvelam a fragilidade da ilusāo realista, os impasses presentes na composição e, finalmente, as questōes que giram em torno do modo de ser da literatura.

Este é portanto um exemplo de enlace do Quixote com uma grande obra da literatura brasileira que se dá essencialmente por meio das letras. Se consideramos o outro eixo - o das armas - o enfoque incide sobretudo na personagem e nas relações entre a história e a ficção. A personagem, por sua vez, encarna um projeto que se apresenta de forma mais ou menos explícita e que incide no âmbito rural ou urbano, com caracteristicas de cunho mais social ou mais cultural. Seguindo os passos da obra cervantina, a personagem está mergulhada numa motivaçāo heróica. No entanto, este heroísmo tem o viés da loucura, o que abre espaço para a marginalização como forma de exclusão social. Este eixo abarca portanto um repertório amplo de romances nos quais, com maior ou menor estratégia, a personagem esteve empenhado numa transformação da sociedade.

No caso do Quixote, o inusitado cavaleiro da Mancha dispōe de duas motivaçōes que são as grandes responsáveis pelo seu equivoco irremediável: por um lado acredita que as novelas de cavalaria são verdadeiras e portanto confunde, ou melhor, identifica a verdade histórica com a verdade poética; por outro lado, está convencido de que é capaz de restituir ao mundo a ordem inquebrantável da cavalaria andante e assim tem plena confiança na força de seu braço, ignorando. entre outras coisas, os já avançados cinqüenta anos.

No âmbito da literatura brasileira, o Triste fim de Policarpo Quaresma de Lima Barreto é sem dúvida um romance de marcadas feições quixotescas. Policarpo encarna

leitor. Tu tens pressa de envelhecer, e o livro anda devagar; tu amas a narração direita e nutrida, o estilo regular e fluente, e este livro e o meu estilo são como os ébrios, guinam à direita e à esquerda, andam e param, resmungam, urram, gargalham, ameaçam o céu, escorregam e caem ..." (Memórias póstumas de Brás Cubas. Ed.de J. De Nicola. São Paulo, Ed. Scipione, 1994, Cap. LXXI, p. 81.) 
um projeto épico e propōe alternativas que orientem os tortuosos caminhos da naçāo ${ }^{6}$. Busca as raízes brasileiras num momento em que as referências estrangeiras - especialmente os modelos da vida urbana parisiense - vão se impondo na vida nacional em meio a profundas contradiçōes sociais e políticas. A ideologia do êxito social econômico e da ascensāo social vão ganhando espaço quando ainda predominam valores e estruturas tradicionais ${ }^{7}$

Assim como Dom Quixote, Policarpo Quaresma esteve dedicado às armas: foi comandante militar e no momento se ocupa da burocracia no Arsenal de Guerra. Da mesma forma, dispõe de uma biblioteca particular onde deixa consumir suas horas de lazer, estudando assuntos variados que envolvem a Pátria. Trata-se de um tipo tímido que não dispõe da grandiloqüência quixotesca. Deixa a impressão de ter passado a vida dialogando com os livros, submerso num profundo silêncio. Como Dom Quixote, por volta dos cinqüenta anos, torna público seu projeto acerca da reforma lingüistica que trata da implantação do tupi como lingua oficial do Brasil. Não demora muito para tornar-se vítima da opinião pública que não hesita em excluí-lo da soci-

(6) Numa conferência intitulada “Dom Quixote" (Conferências literárias. Rio de Janeiro, Francisco Alves, 1912, p. 173-196.), Olavo Bilac chama a atenção para a presença de um sentido quixotesco na formação da história brasileira, como se graças à criação de Cervantes, a ficção tivesse inundado a realidade. Como se os passos árduos dos colonizadores portugueses, ao longo do processo de fundaçāo da nacionalidade, tivessem encontrado sua fonte de inspiraçāo nas andanças de Dom Quixote. É curiosa a intersecção que Bilac estabelece entre história e ficçāo, atribuindo ao Cavaleiro da Mancha um sentido transformador, como se o espírito quixotesco estivesse imbricado tanto nas dificuldades quanto nas glórias de nossos colonizadores, respaldados sempre por um sentido épico.

(7) Lima Barreto (1881-1922) nasce num momento de muitas mudanças: "É o império a ruir dando lugar a uma República oligárquica, onde os esquemas sociais tradicionais se repetem, sem se verificar uma estrutura mais profunda no processo histórico da sociedade brasileira. Por outro lado, a República não havia significado a modernização que, com base na acumulação de capital originário da economia cafeeira, se esboçara, desde o último quartel do século XIX." (Ver de Afonso Carlos Marques dos Santos, "Lima Barreto e as contradições sociais de seu tempo" em O Rio de Janeiro de Lima Barreto. Rio de Janeiro, Prefeitura da Cidade do Rio de Janeiro / Secretaria Municipal de Educação e Cultura / Rioarte, 1983, Vol. 2, p. 21.) 

quixotescas

edade, internando-o num manicômio. De qualquer forma, sua convicção acerca da urgência de reformas não se debilita e não demora muito para elaborar um novo projeto relacionado agora com a recuperação da agricultura nacional, o que, evidentemente, não recebe a menor atençāo do Presidente da República. Novamente, um novo mecanismo de exclusão social é acionado e, desta vez, Policarpo terá que suportar a prisão. Vitima de um profundo desengano, Policarpo abandona suas idéias quixotescas e assim como Dom Quixote, após inúmeras aventuras, já não acredita na possivel transformação da ordem das coisas.

A configuraçāo quixotesca da personagem não se limita ao inconformismo que se consumiu em anos de silêncio repletos de espelhismos ${ }^{8}$ ou ao seu afã de erudição unido a disparatadas idéias nacionalistas. Sua convivência social é limitada e seus interesses são incompativeis com os da sociedade, especialmente com relação à classe dominante que se aperfeiçoa no prosaísmo e na imediatez dos horizontes. Seu entorno doméstico também guarda semelhanças com o de Dom Quixote pois conta com duas personagens femininas que, em alguma medida, correspondem à ama e à sobrinha: trata-se da irmã solteira que cuida da casa e não tem muita paciência para suportar as idéias disparatadas do irmão e da afilhada, sua interlocutora, capaz de compreender seus desvarios. Além disso, conta também com um amigo - Ricardo Coração dos Outros - que faz as vezes de

(8) Ver de Antonio Arnoni Prado, Lima Barreto: o crítico e a crise (São Paulo, Martins Fontes, 1989, p. 3-23). É importante ter em conta que ao publicar Triste fin de Policarpo Quaresma, Lima Barreto foi considerado pela crítica como um legítimo sucessor de Machado de Assis. Apesar do talento literário, ao longo de sua vida Lima Barreto teve que enfrentar inúmeros problemas, inclusive psicológicos e, assim como seu personagem Policarpo Quaresma, pôde conhecer a realidade dos manicômios. Nos momentos mais difíceis ele tenta se amparar na literatura, em obras e autores tal como aparece em seu Diário íntimo (Rio de Janeiro, Ed. Mérito, s/f [1953], p. 172) quando trata de se consolar lembrando-se das dificuldades pelas quais passou Cervantes no cativeiro em Argel. Sobre a biografia de Lima Barreto ver de Francisco de Assis Barbosa, A vida de Lima Barreto (Belo Horizonte, Itatiaia, São Paulo, Edusp, 1988, 7. ed.) 
um Sancho Pança pois, sendo negro e pobre, está à margem do sistema ao mesmo tempo que constitui o grande interlocutor de Policarpo.

Mas o quixotismo de Policarpo tem raizes mais profundas pois brota do desencontro entre a sua visão e a da sociedade que correpondem, respectivamente, ao sonho utópico contraposto a um Brasil arcaizante. A partir do riso provocado por suas loucuras nasce a vertente comovedora de seu idealismo que não tem origem, especificamente, no disparate de seus espelhismos mas sim no fato de que o protagonista, louco ou sensato, é fiel a si mesmo. Assim como no Quixote, esta imbricação do trágico e do cômico parece se estruturar sobre um projeto grandioso, ou seja, uma matéria própria da épica que teve que se conformar com o deslocamento para o âmbito da lírica, circunscrito aos impulsos da subjetividade.

Assim como na obra de Cervantes, o herói parece ter cumprido os desígnios de Ulisses: seu entorno social já não comporta grandes ambições e em vez do heroismo memorável que faz a história, suas idéias fora de tempo e de espaço se converteram em manifestaçōes marginais da loucura.

\begin{abstract}
The Don Quixote, having established a new kind of literature, has generated a whole offspring of narratives which incorporate different aspects of its construction. Primarily, the following article concerns some of Don Quixote's aesthetic qualities that are visible in Machado de Assis' Memórias Póstumas de Brás Cubas. After that, it will broach Lima Barreto's Triste Fim de Policarpo Quaresma, showing another kind of fliation which leads to the question of the hero's constitution, taking into account the imbrications between the epic and the liric, as well as the paradoxal fusion of heroism and craziness.
\end{abstract}

Keywords: Don Quixote, novell, hero, literary kinds, narrator/reader. 